\title{
A NEW LARGE-FLOWERED ODONTOGLOSSUM (ORCHIDACEAE: ONCIDIINAE) FROM THE CUSCO REGION IN PERU
}

\author{
Stig DalströM ${ }^{1,3} \&$ SAUl Rúiz Pérez ${ }^{2}$ \\ ${ }^{1} 2304$ Ringling Boulevard, unit 119, Sarasota FL 34237, U.S.A. \\ Lankester Botanical Garden, University of Costa Rica, Cartago, Costa Rica \\ and National Biodiversity Centre, Serbithang, Bhutan \\ ${ }^{2}$ Allamanda 142, Surco, Lima 33, Peru \\ ${ }^{3}$ Corresponding author: stigdalstrom@juno.com
}

\begin{abstract}
Plants of a colorful Odontoglossum were recently found by separate parties in the Cusco region of central Peru. The species was incorrectly identified as Odontoglossum epidendroides, independently by both parties. Although similar in appearance, a closer examination of the flower reveals that it represents a new species, which is scientifically described here and compared with similar species. The new taxon is distinguished from the similar $O$. cruentum and $O$. juninense by morphological features of the column, such as the lateral curvature profile, with larger and more rectangular wings, and in combination with the well developed falcate callus structure on the lip. Our new species is also distinguished from the rather similar $O$. epidendroides by having flowers with a shorter column with shorter wings.
\end{abstract}

Key words: Orchidaceae, Oncidiinae, Odontoglossum, new species, Cusco, Peru, taxonomy

The genus Odontoglossum Kunth (treated by some authors as Oncidium), has revealed miscellaneous new species in recent time. Some are rather similar to closely related taxa while others show surprisingly distinct morphologic features, such as the floristically diminutive Oncidium koechlinianum Collantes \& G.Gerlach (2011), which was transferred to Odontoglossum by Dalström (2012a, where valid reasons for maintaining the taxonomic status of the genus is argued and outlined). Recent fieldwork performed by the authors and others also show that some previously lumped or misidentified taxa deserve an elevated taxonomic status, such as Odontoglossum furcatum Dalström (2012b), and the species published here.

Odontoglossum auroincarum Dalström \& RuízPérez, sp. nov.

TYPE: Peru. Cusco. Alfamayo, ca. $2600 \mathrm{~m}, \mathrm{~S} 13^{\circ}$ 03.647'; W 72 24.351', Dec. 3, 2011. S. Dalström 3594 (holotype, USM). Figs. 1, 2A, 2A1, 2A2, 3, 4).

Diagnosis: Odontoglossum auroincarum is similar to O. epidendroides Kunth (Figs. 2E, 2E1, 2E2, 5), but differs from it by having flowers with a shorter ( $c a$.
10-11 mm long versus $13-14 \mathrm{~mm}$ ), and differently curved column with shorter wings. It differs from O. cruentum Rchb.f., (Figs. 2B, 2B1, 2B2, 6), and O. juninense Schltr. (FIGs. 2D, 2D1, 2D2, 7), by a different lateral curvature profile of the column, with broader and more rectangular column wings as well as a less lobulate anther-cap.

Epiphytic herb. Pseudobulbs caespitose, ancipitous, ovoid to pyriform, glossy, bifoliate, $4-5 \times 7-8$ $\mathrm{cm}$, surrounded basally by 5 to 7 distichous sheaths, the uppermost foliaceous. Leaves subpetiolate, conduplicate, elongate elliptic to slightly obovate, acuminate $27-31 \times 2.5-3.0 \mathrm{~cm}$. Inflorescences axillary from the uppermost sheaths, erect to arching, weakly fractiflex 12- to 15 -flowered racemes, or up to 25-flowered widely branched panicles (old inflorescences on type specimen). Pedicel with ovary $2.0-2.5 \mathrm{~cm}$ long. Floral bracts appressed, scalelike to $c a .1 \mathrm{~cm}$ long. Flower relatively large and showy, stellate; dorsal sepal dark yellow with large irregular red-brown spotting, cuneate, ovate laminate, acuminate and slightly oblique, $c a .35 \times 10-11 \mathrm{~mm}$; lateral sepals similar in color, slightly unguiculate, ovate laminate, acuminate, slightly oblique, $c a$. 

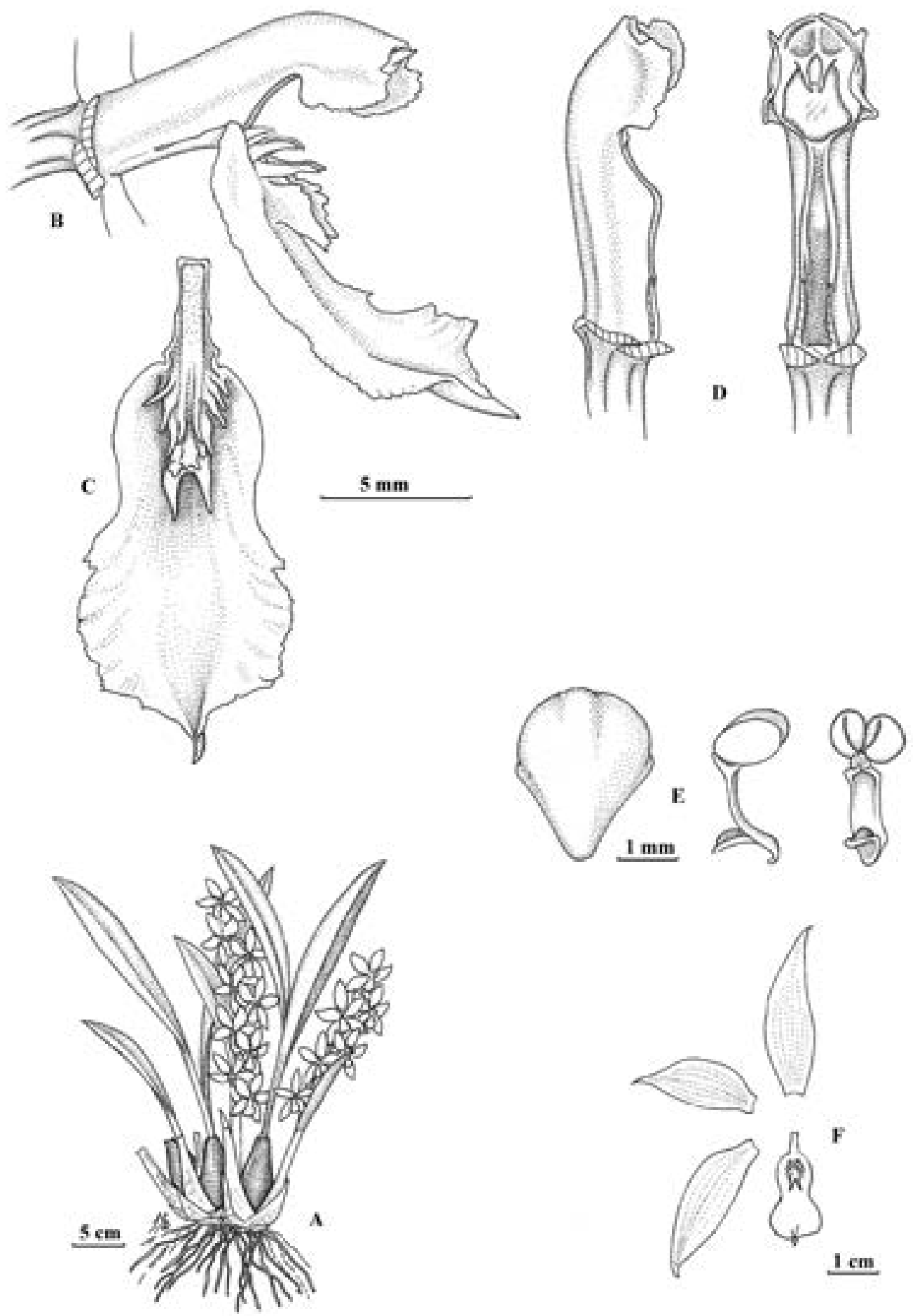

FigURE 1. Odontoglossum auroincarum. A - Plant habit. B - Column and lip, lateral view. C - Lip, frontal view. D Column, lateral and ventral views. E- Anther cap, dorsal view, and pollinarium, lateral and back views. F - Flower dissected. Drawn from holotype by Stig Dalström. 

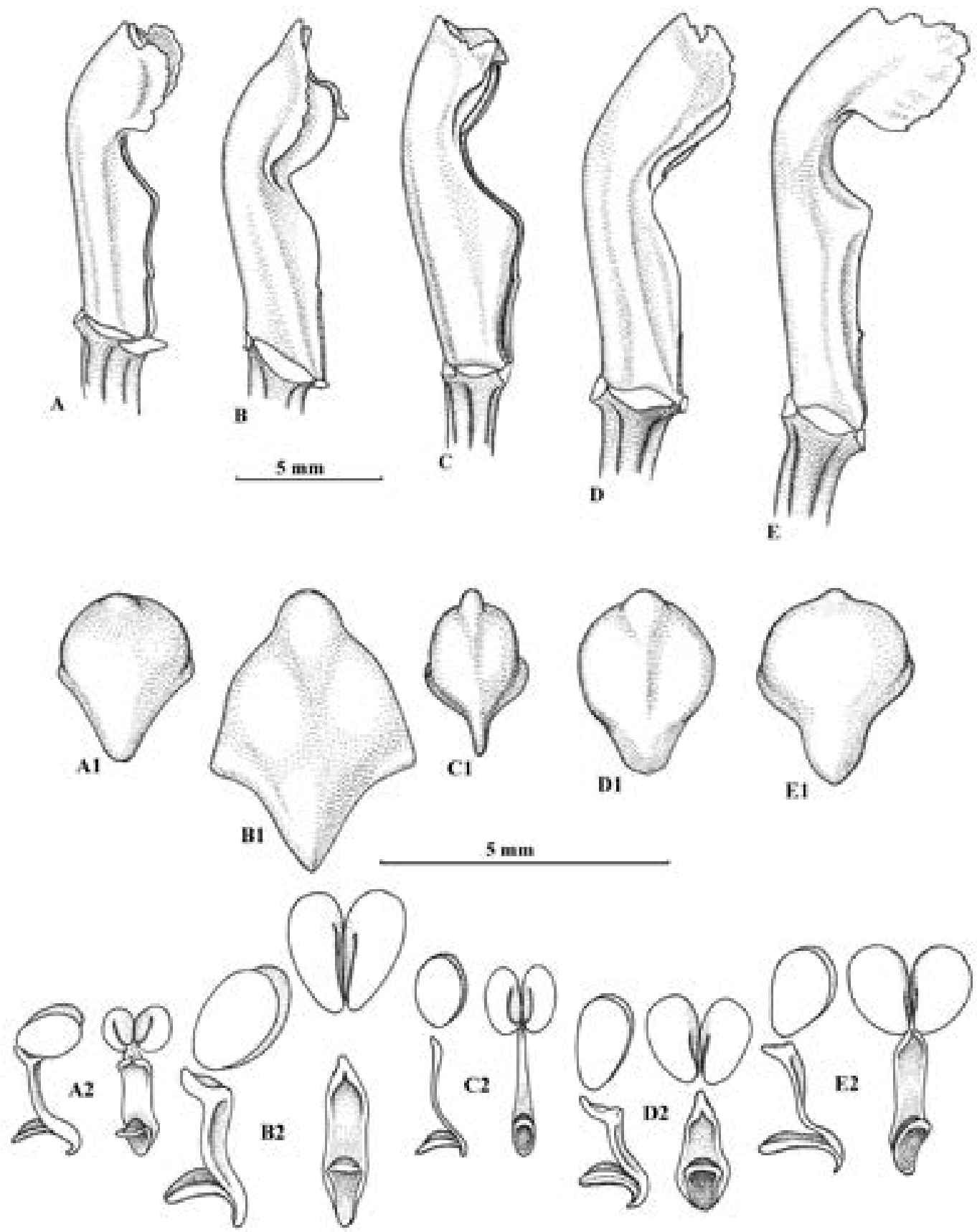

Figure 2. A. Odontoglossum auroincarum, (S. Dalström 3594, USM), column lateral view. A1. Anther cap dorsal view. A2. Pollinarium lateral and back views. B. Odontoglossum cruentum (S. Dalström 481, SEL), column lateral view. B1. Anther cap dorsal view. B2 Pollinarium lateral and back views. C. Odontoglossum subuligerum (S. Dalström 3611, USM), column lateral view. C1. Anther cap dorsal view. C2. Pollinarium lateral and back views. D. Odontoglossum juninense (S. Dalström 2378, Dalström archives), column lateral view. D1. Anther cap dorsal view. D2. Pollinarium lateral and back views. E. Odontoglossum epidendroides (S. Dalström 3282, USM), column lateral view. E1. Anther cap dorsal view. E2. Pollinarium lateral and back views. Drawn by Stig Dalström. 


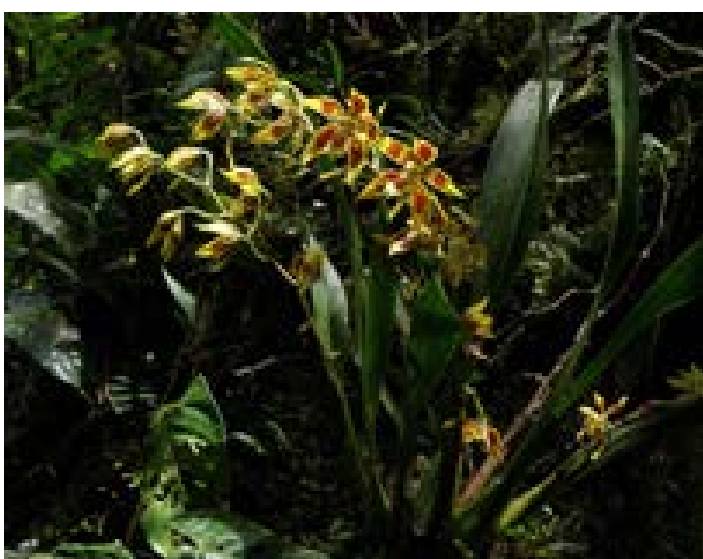

FIgURE 3. Odontoglossum auroincarum, plant habit. Photo by Stig Dalström.

$33 \times 10-11 \mathrm{~mm}$; petals similar in color, broadly unguiculate, ovate laminate, acuminate, oblique, $c a$. $27 \times 8-10 \mathrm{~mm}$; lip similar in color, adnate to the basal and lateral flanks of the column for $c a$. $2.0-2.5 \mathrm{~mm}$, then free and strap-like for $c a .1 \mathrm{~mm}$, apical portion angled downwards into a large, pandurate lamina, with serrate to lacerate frontlobes, and a folded, canaliculate, apiculate apex, $c a .17-18 \times 7-8 \mathrm{~mm}$; callus white, of a fleshy, basally minutely pubescent, central, longitudinal, flattened keel, emerging from the base to $c a$. one third of the length of the lamina, terminating in a shallowly canaliculate, raised ridge, ending with several pairs of acute, projecting angles, with a larger, erect, irregular, denticulate knob, and 3 to 4 pairs of lateral, falcate, variously sized spreading keels; column pale greenish white with some minor brown ventral dots, erect and straight for $c a .2 / 3$ of its length, then curved towards the lip, ventrally canaliculate, basally micro-pubescent, with distinct ventral angles below the stigma, which is covered laterally by a pair of almost rectangular, serrate wings, ca. 10-11 mm long; anther cap pale yellow, campanulate, rostrate, with a minute and low apical lobule; pollinarium of two pyriform, cleft/folded pollinia on a yellow colored, almost rectangular, ca. $1.8 \mathrm{~mm}$ long stipe, on a hooked and pulvinate viscidium.

Other material studied: Peru. Cusco, Urubamba, Machu Picchu, collected in the Machu Picchu Sanctuary and cultivated in the garden of the INKATERRA Machu Picchu Pueblo Hotel, photo by Benjamín Collantes in

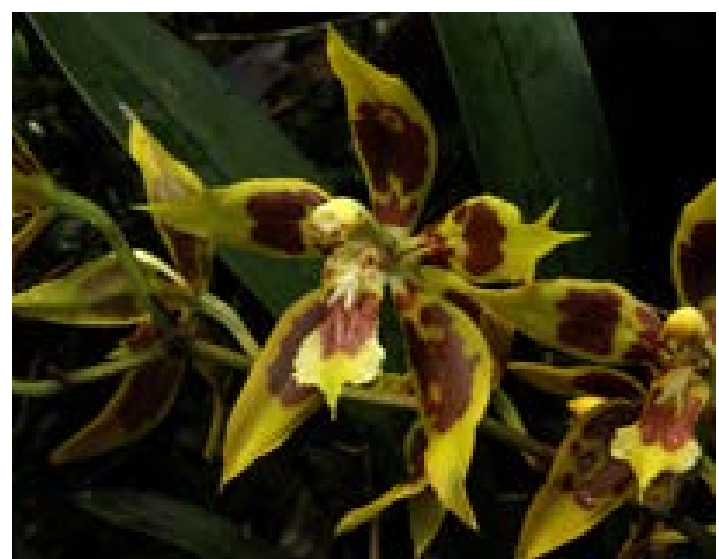

FIGURE 4. Odontoglossum auroincarum, flower in close-up. Photo by Stig Dalström.

"Orquideas en InKaterra Machu Picchu Pueblo Hotel" (Collantes et al. 2007).

Distribution: Known only from the cloud forests of Alfamayo, and from the Machu Picchu sanctuary in the Urubamba region of Cusco, central Peru.

Etymology: The name refers to the golden yellow color of the flowers of this species and is a tribute to 'botanical Inca gold', which comes from the area in Peru that once was the center of the powerful Inca culture.

The first plants of Odontoglossum auroincarum were collected within the borders of the Machu Picchu sanctuary by the staff of the INKATERRA hotel. Plants were replanted in the orchid garden of the hotel and flowered there. Photos of the flowers were then taken by Benjamín Collantes and published, labeled "Odontoglossum epidendroides" (Collantes et al. 2007). A few years later, plants were found in the Alfamayo region by the second author of this paper, and brought into cultivation for propagation. When the plants flowered they were still believed to be $O$. epidendroides, but with some question marks. Eventually a detailed drawing of the flower could be made, which was compared with drawings of similar species. The conclusion was that a new and attractive species had been discovered. Although superficially and rather confusingly similar to several other yellow flowered species, the morphological features of the column and lip structure as well as the anther and pollinarium are quite distinct and display 


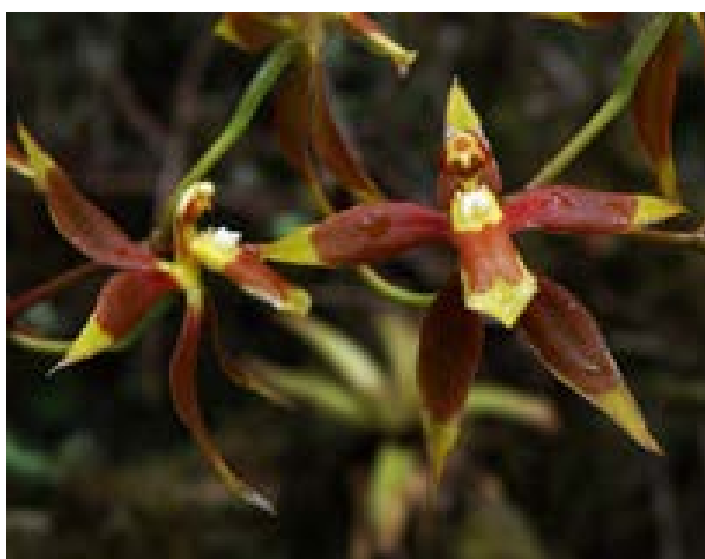

FIGURE 5. Odontoglossum epidendroides, flower in close-up. Photo by Stig Dalström.

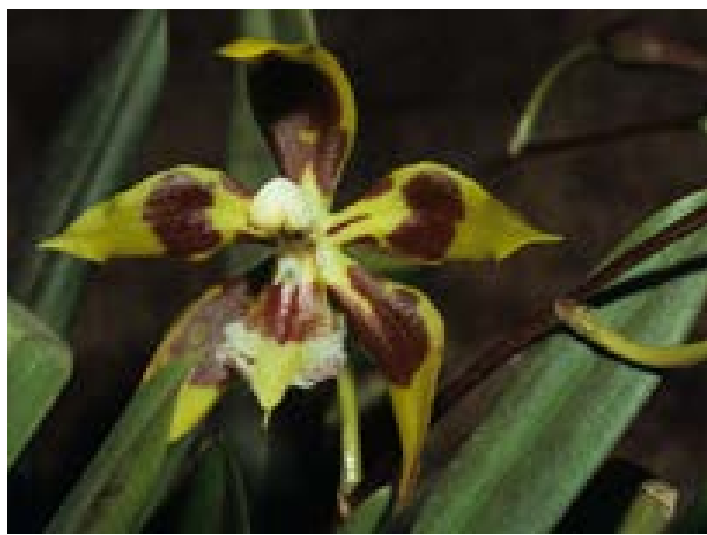

FIGURE 7. Odontoglossum juninense, flower in close-up. Photo by Stig Dalström.

a combination of characteristics that create a unique species profile. The only sympatric Odontoglossum species of this particular complex with a flexible lip is O. subuligerum Rchb.f. (Figs. 2C, 2C1, 2C2, 8) which is easily distinguished by the large knob on the anther cap and by the extremely narrow pollinarium stipe.

AcKnOwLedgements. The authors wish to thank the staff at the Instituto Recursos Naturales (INRENA), and Betty Millán at the Universidad de San Marcos, Museo de Historia Natural, Lima, for aiding in providing the necessary collecting permits. We also thank Wesley Higgins for commenting on the manuscript, Steve Beckendorf, Guido and Karel Deburghgraeve for stimulating company in the field, and Manolo Arias together with his staff and family in Lima for gracious logistic support.

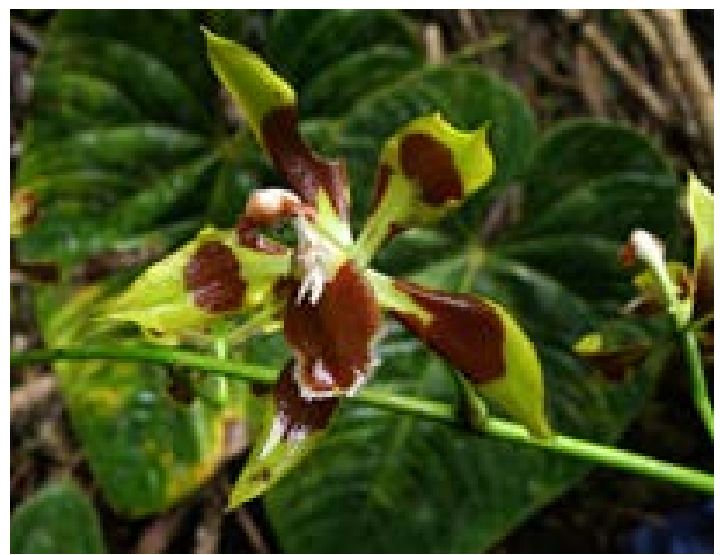

FIGURE 6. Odontoglossum cruentum, flower in close-up. Photo by Stig Dalström.

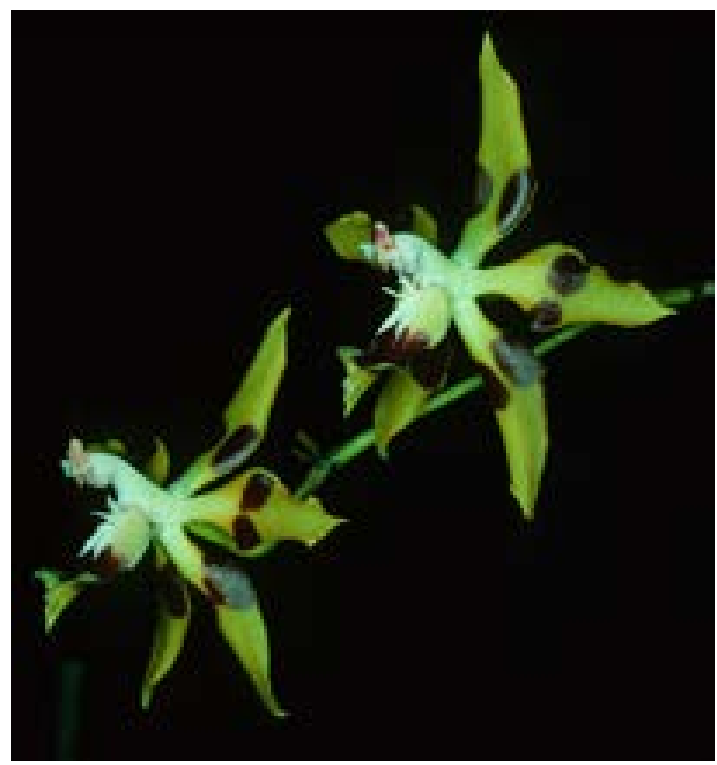

Figure 8. Odontoglossum subuligerum, Chapare, Bolivia, flowers close-up. Photo by Jan Sönnemark.

\section{LiTERATURE CITED}

Collantes, B., C. Soto \& J. Koechlin. 2007. Orchids Orquídeas en Inkaterra Machu Picchu Pueblo Hotel. Inkaterra Asociación, Lima, Perú.

Collantes, B. \& G. Gerlach. 2011. Über zwei neue Orchideen aus Machu Picchu (Peru) aus der Subtribus Oncidiinae. OrchideenJournal (2): 79-81.

Dalström, S. 2012a. New combinations in Odontoglossum (Orchidaceae: Oncidiinae) and a solution to a taxonomic conundrum. Lankesteriana 12(1): 53-60.

Dalström, S. 2012b. A well-known but previously misidentified Odontoglossum (Orchidaceae: Oncidiinae) from Ecuador. Lankesteriana 12(3): 155-160. 
